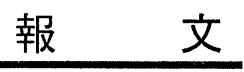

\title{
ポリ（オキシエチレン）硬化ひまし油系非イオン 界面活性剂のベシクル形成性について
}

\author{
堀内 照夫 - 田嶋 和夫* \\ ライオン株式会社第一開発研究室 ( \\ * 神奈川大学工学部化学教室（干221 横浜市神奈川区六角橋 3-27）
}

Vesicle Formation of Poly(oxyethylene) hydrogenated Castor Oil having Nonionic Surfactant Properties

Teruo HoRIUCHI and Kazuo TAJIMA*

Development Laboratory I, Lion Corporation

(3-7 Honjyo 1 chome, Sumida-ku, Tokyo, ₹130)

* Department of Chemistry, Faculty of Engineering, Kanagawa University

(3-27, Rokkakubashi, Kanagawa-ku, Yokohama-shi, T221)

\begin{abstract}
Vesicle formation of poly(oxyethylene) hydrogenated castor oil derivatives was studied by polarized microscopy, freeze-fractured electron microscopy, particle size analysis, ESR spin labelling, and small angle $\mathrm{X}$-ray diffraction.

It comes to conclusions that poly (oxyethylene) (10) hydrogenated castor oil ( $\mathrm{HCO}-10)$, in to which 10 moles of oxyethylene moieties of are incorporated, has liquid crystals at $5 \sim 60 \mathrm{wt} \%$ of concentration below $40^{\circ} \mathrm{C}$. A multilamellar vesicle with ca. $400 \mathrm{~nm}$ of an average diameter of was formed at a $\mathrm{HCO}-10$ concentration below $20 \mathrm{wt} \%$. The properties of the $\mathrm{HCO}-10$ vesicle membrane are discussed in terms of anistropy in the ESR spectra and long spacing observed by $\mathrm{X}$-ray diffraction.
\end{abstract}

\section{1 緒言}

1965 年, 英国の Bangham は天然由来のリン脂質を 過剩の水に分散させると, 二分子膜から成る閉鎖小胞体 (closed bilayer) が形成されることを見いだし，これ

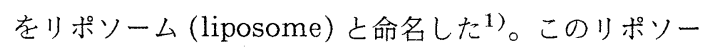
ム膜の脂質マトリックスの基本構造は生体膜と類似の隔 壁性を有することから, 生体膜のモデル膜として注目さ れた。そこで,このリポソームはイオンの透過性の研究 ${ }^{2)}$ を初めとし, 薬物の担体 $(\mathrm{DDS})^{3), 4)}$ や反応場 (物質, エネルギー, 晶析) 5 ) 7)などとしての使用が可能のため 多くの基礎研究や実用化のための応用研究が行われてい る。

リポソーム膜を構成しているリン脂質, 特にレシチン を膜形成化合物の観点から眺めると, レシチンは天然由 来の両親媒性化合物であるため, 生体適合性, 標的指向 性の点では優れた特徴を有している。しかし, その反 面, レシチンは天然由来であるがために医薬品または,

連絡者 : 堀内照夫
各種工業分野への応用を考えるさいその化学構造に制限 され, 機能付与のため化学修飾が行いづらく, その上, リポソームの調製が煩雑でしかも化学的及び物理的に不 安定であることなど多くの問題を内在している。

Kunitake $^{8)}$ らは, 生体膜を構成する脂質マトリック スの基本構造が 2 本の長鎖アルキル基と親水基に基づく と仮定し, ジアルキルアンモ二ウム塩の水溶液中の会合 状態について検討したところ, 安定な閉鎖 2 分子膜小胞 体（ベシクル）が形成されることを見いだした。その 後, 化学構造の異なる一連の両親媒性化合物について, それらの水溶液中での分子集合状態が広範囲に研究され ている。その結果, 一鎖型の両親媒化合物に (1) rigid segment, (2) 尾部アルキル鎖長, (3) アミドやエステ ル結合のような分子間相互作用基, (4) スペーサーアル キル基, (5) 親水基の構造などを導入したり, 変えるこ とにより, 一鎖型の化合物でもべシクル, 球状, ひも 状，ディスク状の様々な分子集合体を形成するというこ とが報告されている ${ }^{9)}$ 。この事により，2 分子膜を形成 する現象は, 生体膜由来のレシチン特有の性質でなく, 
リポソーム膜構筑のための基本構造さえ備えていれば, 広範囲な有機化合物に一般的に見られることがわかり， リポソーム膜の構成成分の多様化が可能亡なった。

最近, 膜を形成する両親媒性の化合物の中で, 特に, 非イオン性の両親媒性化合物が synthetic tailormade lipid として注目されている。それはイオン性の 両親媒性化合物と比較して, 生理的安全性が高く, その 上, 種々の機能付与のための分子設計が比較的容易なこ となどによるからである。

Handjiani-Vila ${ }^{10)}$ らは，モノマー型非イオン性の 両親媒性化合物，ポリグリセリンエーテルから成るリポ ソーム（ニオソーム）について興味ある研究を報告して いる。このニオソームに ${ }^{14} \mathrm{C}$ で標識したピロリドンカ ルボン酸を埋め込み，その経皮吸収性をエマルションや ミセル等の剤型と比較して, リポソーム剂型はピロリド ンカルボン酸の皮膚に対する浸透性を著しく向上すると

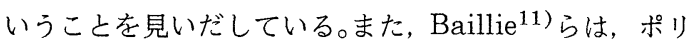
グリセリン誘導体を用い，5(6)一カルボキシルフルオレ セイン $(\mathrm{CF})$ の放出挙動を報告している。Okahata ${ }^{12)}$ らは，一連の二鎖型のポリ(オキシエチレン) ジアルキ ルグリセリン誘導体を合成し, ベシクル形成性に対する アルキル鎖長の長さとエチレンオキシド ( $\mathrm{EO})$ の付加モ ル数の関係について報告している。しかし，オリゴマー 型の非イオン性の両親媒性化合物によるベシクルの形成 性やベシクル膜の会合状態についての研究はこれまで,

ほとんど報告がない。

我々は, 化粧品または医薬品なざの乳化剂や可溶化剂 などの基剤として古くから使用されているオリゴマー型 の非イオン性両親媒性化合物であるポリ（オキシエチレ ン）硬化ひまし油誘導体に注目し，その水溶液中での分 子集合状態について研究を行っている13),14)。

本研究では, ポリ(オキシエチレン) 硬化ひまし油の ベシクル形成性を偏光顕微鏡像, 凍結割断電子顕微鏡, 粒子径測定, 相図, 小角散乱 X 線回折, ESR スピンラ ベル法などによって検討したので報告する。

\section{2 実験}

\section{$2 \cdot 1$ 試 料}

Fig. -1 に示すエチレンオキシド (EO) 付加モル数の 異なるポリ(オキシエチレン) 硬化ひまし油誘導体（一 般に, $\mathrm{HCO}-\mathrm{E}$ と略し，Eはエチレンオキシド $(\mathrm{EO})$ の 付加モル数を示し, $E=l+m+n+x+y+z)$ は, 日光ケミ カル (株) から購入し，そのまま用いた。

Fig.ー2 は用いたポリ(オキシエチレン)硬化ひまし油 誘導体の $\mathrm{EO}$ 付加モル数と HLB 值及び有機概念図法 ${ }^{15)}$ をもとに計算した IOB 值 (inorganic/organic balance) の関係を示す。

\section{$2 \cdot 2$ ベシクルの調製}

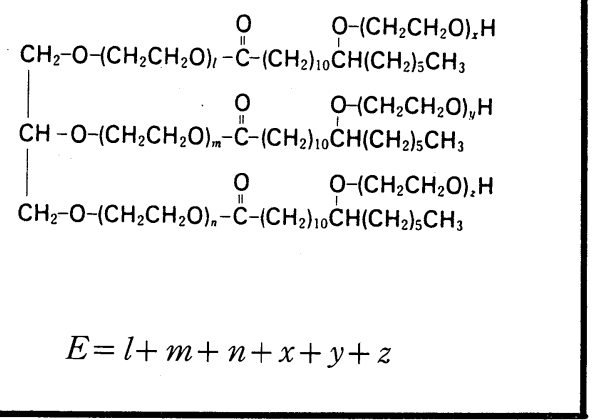

Fig.-1 Chemical structure of poly (oxyethylene) hydrogenated castor oil.

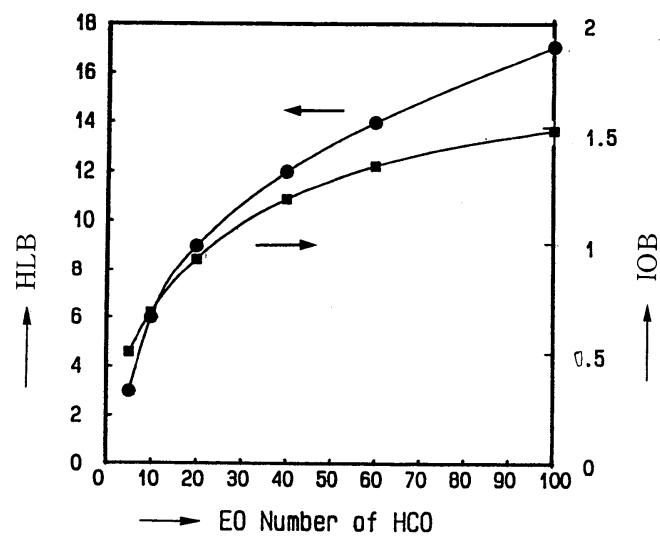

Fig.-2 Relationship between HLB or IOB and EO number of HCO.

ベシクル形成性を調べるため, 分散溶液は所定量のポ リ(オキシエチレン) 硬化ひまし油誘導体を蒸留水に添 加し, かくはん機で $100 \mathrm{rpm}, 30 \mathrm{~min}$ 良く混合し調製 した。また, ベシクル形成の確認は必要に応じその分散 溶液の偏光顕微鏡及び凍結割断法電子顕微鏡観察並びに 粒子径測定により行った。

\section{$2 \cdot 3$ 測 定}

\section{$2 \cdot 3 \cdot 1$ 液晶の観察}

相図作成のため, 各分散溶液中における界面活性剂の 会合状態は偏光顕微鏡（オリンパス製， BH 型）を用い て観察した。すなわち, 種々の濃度に調製した試料（約 $2 \mathrm{mg}$ )をスライドグラスの上に取り, カバーグラスで その上面を覆い，水分の蒸発を防ぐため，周囲をコロジ オン膜でシールした。また, 分散溶液の状態は必要に応 じ, 自製の加熱ステージ（昇温速度：約 $1^{\circ} \mathrm{C} / \mathrm{min}$ )を用 いて観察した。

\section{$2 \cdot 3 \cdot 2$ ベシクル粒子の観察}

各分散溶液のベシクル形成性は凍結割断法による電子 顕微鏡観察（日立製，H-600 型）により判定した。ま 
た, それらのベシクルの平均粒子径はサブミクロンパー デクルサイザー (Brookhaven Instruments Co., BI-90) で測定した。

\section{$2 \cdot 3 \cdot 3$ 層間距離の測定}

ポリ(オキシエチレン) 硬化ひまし油の濃度 (wt \%)が 異なる分散溶液の層間距離の測定は密封セル（マイラー フィルム, スペーサー: $1 \mathrm{~mm}$ ) を用い, 小角散乱X 線 回折装置（理学電機製, RAD-RB型）で行った。

$2 \cdot 3 \cdot 4$ ポリ(オキシエチレン) 硬化ひまし油の会合状 態

ポリ(オキシエチレン) 硬化ひまし油の会合状態は ESR スピンラベル法によって評価した。スピンラベル 法は常法に従い次のように行った。まず, 5-, 12-, 及 び 16-ドキシルステアリン酸 (5 NS, 12 NS, 16 NS, Sigma Chem. Co.) のスピンプローブをエタノールに 溶かして各 $1 \times 10^{-4} \mathrm{~mol} \cdot \mathrm{dm}^{-3}$ の溶液を調製した。こ の溶液 $2 \mathrm{~g}$ を $10 \mathrm{~mL}$ のバイアル瓶に取り, $60 \sim 70^{\circ} \mathrm{C}$ の 水浴上で $\mathrm{EtOH}$ を留去した後, あらかじめ調製してお いた各種ベシクル分散溶液 $2 \mathrm{~g}$ を取り, ミキサーを用い 2 日間良く振とうし, 混合溶解させた。そして, これら の試料をガラス製のキャピラリー（内径 : $0.85 \mathrm{~mm}$ ) に 少量取り, 両端をよう(熔)封して, 電子スピン共鳴装置 (日本電子製, JES-FE) で ESR スペクトルを测定し た。異方性パラメーターは ESR スペクトルから, $2 A_{/ /}$ 及び2 $A_{\perp}$ を読み取り，

異方性パラメーター $(G)=2\left(A_{/ /}-A_{\perp}\right)$ より計算した。

\section{3 結果及び考察}

\section{$3 \cdot 1$ ポリ(オキシェチレン) 硬化ひまし油のベシクル 形成性}

セッケン，レシチン等の両親媒性化合物は一般にその 濃度や温度によって, 種々な分子集合体を形成すること
が知られている16)。

ポリ(オキシエチレン)硬化ひまし油は, ひまし油の主 成分であるリシノール酸(ricinoleic acid)の特性 $\left.{ }^{17}\right), 18$ ) を生かしたオリゴマー型の非イオン性両親媒性化合物で あり, 低刺激, 低毒性で安全性が大変高いことから, 脂 溶性薬物の注射用及び内服用可溶化剂を初め, 化粧品基 剤として，古くから使用されている ${ }^{18) 。 ~}$

Table-1は偏光顕微鏡観察により, ポリ（オキシエチ レン) 硬化ひまし油誘導体 $(\mathrm{HCO}-\mathrm{E})$ の会合状態に対 する $(\mathrm{EO})$ 付加モル数とその濃度の影響を示したもので ある。

それぞれの誘導体の分散溶液中で, 層状構造 (ラメ ラー相液晶, N) が観察されたのはポリ(オキシエチレ ン）(10) 硬化ひまし油 (HCO-10) のみで, しかも濃度 5〜60 wt\% の領域であった。(EO) 付加モル数が少ない ポリ(オキシエチレン)（5）硬化ひまし油（HCO-5）は 親水性が充分でないため, 沈殿もしくは, 液状の凝集物 となり, 水に分散しなかった。また, (EO) 付加モル数 が高い HCO 誘導体は, Table-1 の太線に示すように, 低濃度領域で等方性溶液となり, 高濃度領域ではゲル溶 液となった。

以上の結果, ポリ (オキシエチレン) 硬化ひまし油誘 導体の層状構造は, $\mathrm{IOB}=0.69$ で, $5 \sim 60 \mathrm{wt} \%$ の濃度範 囲の大变狭い領域でのみ出現する事が示された。

Fig.ー3 はポリ(オキシエチレン) (10) 硬化ひまし油 の会合状態に対する温度の影響を示したものである。

HCO-10 の室温における外観は, 無色または微黄色 の油状物質である。これを水に添加すると, 濃度によっ て, HCO-10 の外観が変化する。すなわち, 外観は 10 〜20 wt\%の濃度範囲で乳濁色を呈した分散溶液とな り, 30〜60 wt \% の濃度範囲で, 半透明な粘ちょうな溶 液となる。そして, $80 \mathrm{wt} \%$ 以上では均一な透明粘ちょ う溶液となる。一方, 偏光顕微鏡で観察すると, HCO-

Table-1 Phase changes of mixtures of $\mathrm{HCO}-\mathrm{E}$ and water at $25^{\circ} \mathrm{C}$

\begin{tabular}{c|cccccccccccc}
\hline wt $\%$ & & & & & & & & & & & & \\
\hline
\end{tabular}

O.S : Oil susp., I : Isotropic soln., $\mathrm{N}$ : Neat, $\mathrm{I}(\mathrm{G})$ : Isotropic gel soln. $\mathrm{M}$ : Middle. 


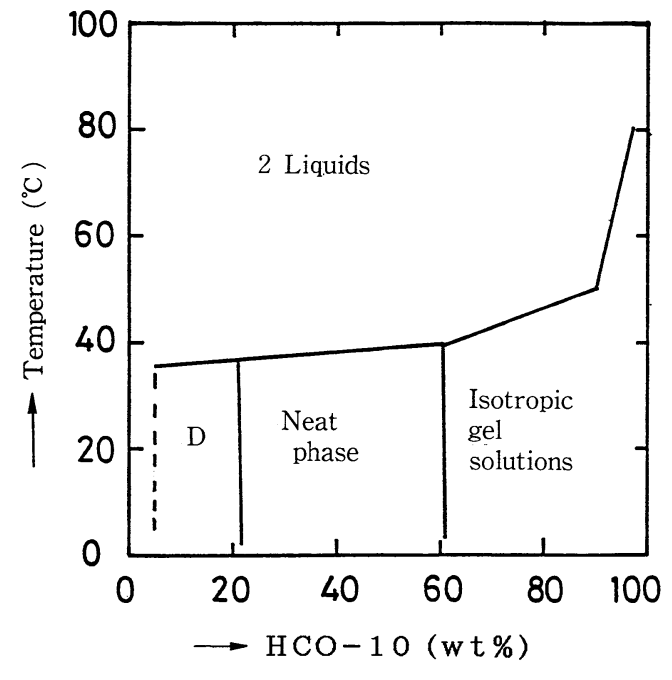

$\mathrm{D}$ : Concentric lamella

Fig.-3 Phase diagram of poly(oxyethylene) (10) hydrogenated castor oil.

10 の濃度 10 60 wt \%, 転位温度 $(T C)$ が $40^{\circ} \mathrm{C}$ 以下の広 範囲でニート相液晶が認められた。しかし, その液晶の テクスチュアーは HCO-10の濃度に応じて変化した。 HCO-10 の濃度が $10 \mathrm{wt} \%$ 近傍で十字ニコル像が観察 され，10２0 wt \% で十字ニコル像と oily streak texture となり, 20〜60 wt \% では oily streak texture のみとなった。

Fig. -3 に示す 10〜20 wt \% の濃度領域の HCO-10 分散溶液は外が乳濁状態で, しかもその偏光顕微鏡像が 十字二コル像を示すので, ベシクル (ニオソーム) 形成 の可能性が示唆される。そこで, HCO-10 分散溶液に ついて, 凍結割断法による電子顕微鏡観察を行った。

10 wt \% の HCO-10 分散溶液から採取した検体を液 体窒素に浸し, 瞬時に凍結させる。次に凍結した固体試 料を適当な部位でカットする。この際, 疎水性相互作用 は温度が低くなると弱くなるので, その破砕面は二分子 膜の疎水性ドメインで切断される。Fig.-4 (A) に 10 wt \%の HCO-10 分散溶液の凍結割断法による電子顕 微鏡写真の一例を示すように同心円状の多重膜ベシクル を形成していることが観察された。

またサブミクロンパーティクルサイザーによる $\mathrm{HCO}$ -10ベシクルの粒子径は約 $50 \sim 2,000 \mathrm{~nm}$ の広範囲に分 布し, その平均粒子径は約 $430 \mathrm{~nm}$ であった。しかし, 30 wt\% 以上で, 偏光顕微鏡像が oily streak texture を示す二ート相液晶領域ではベシクルは観察されず, Fig.-4 (B) に示すような繊維状の分子集合体が観察さ れただけであった。

以上の結果より, Fig. -3 に示す D 領域 ( HCO-10 濃 度：10〜20 wt \%) は concentric lamella 型の液晶形

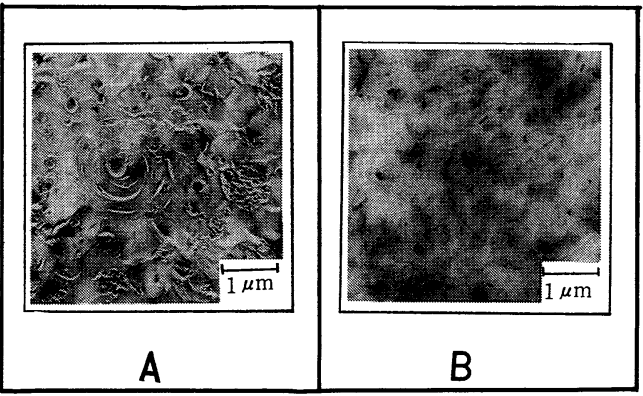

A : HCO-10 concentration is 10 wt $\%$ below $T c$. B : HCO-10 concentration is 40 wt $\%$ below $T c$.

Fig. -4 Freeze-fracture electron micrograph of HCO-10 samples.

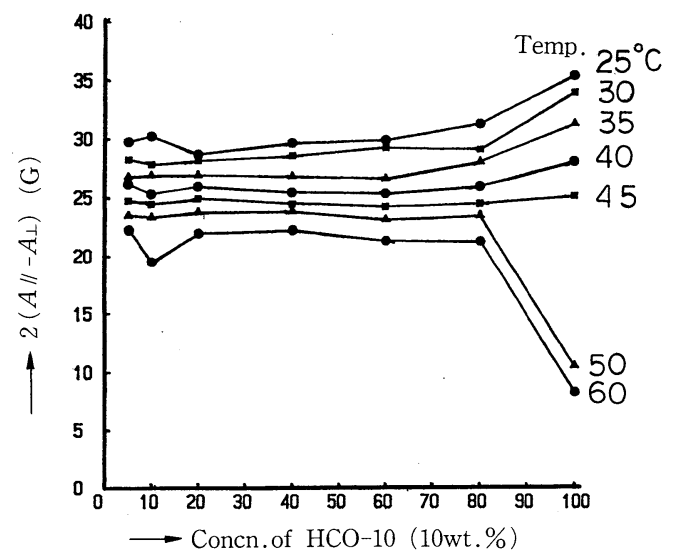

Fig.-5 Effect of HCO-10 concentration on $2\left(A_{/ /}\right.$ $-A_{\perp}$ ) for 5 NS with various temperature.

成領域であると結論した。

\subsection{HCO-10 ベシクル分散溶液の会合状態}

$\mathrm{HCO}-10$ は濃度 $10 \sim 60 \mathrm{wt} \%$, 温度 $40^{\circ} \mathrm{C}$ 以下の広範 囲な領域でニート相液晶を示す。しかし, ニート相液晶 のtexture は HCO-10 の濃度に応じて変化することが わかった。その会合構造はFig. -4 に示すように, 閉鎖 二分子膜小胞体であるベシクルから二分子膜の二ート相 液晶へ変化することが凍結割断法電子顕微鏡観察の結果 から確認された。そこで, これらの分子集合体の会合状 態と層間距離に対する $\mathrm{HCO}-10$ の濃度の影響を ESR スピンプローブ法と小角散乱 X 線回折法によって検討 した。

Fig.-5 は HCO-10 の分子会合体に標識したスピン プローブ(5 NS) の異方性パラメーター $\left[2\left(A_{/ /}-A_{\perp}\right)\right]$ に対する $\mathrm{HCO}-10$ の濃度と温度の影響を示したもので ある。 $25^{\circ} \mathrm{C}$ におけるスピンプローブ (5 NS) の異方性 パラメーターは, HCO-10 の濃度が 5〜60 wt \% の範囲 でほぼ一定となるが， $60 \mathrm{wt} \%$ 以上となると増加した。 
このことは, Fig.ー3に示したように，二ート相液晶か ら粘ちょうなゲル溶液に転移するため, HCO-10 の分 子運動性が束縛されることと, $\mathrm{HCO}-10$ の濃度上昇に 伴い, 分子内または分子間水素結合が形成されるためと 考えられる。一方, 温度が上昇する場合, 異方性パラ メーターの値は $25^{\circ} \mathrm{C}$ のときと, ほぼ同じパターンで減 少した。しかし, 温度が $45^{\circ} \mathrm{C}$ より以上で, $\mathrm{HCO}-10$ の 濃度が 80 100 wt \%での領域において, 異方性パラ メーターは急激に減少した。これは, $\mathrm{HCO}-10$ の分子 内または, 分子間水素結合が切断し, $\mathrm{HCO}-10$ 分子の 熱運動性が急に増加するためと考えられる。

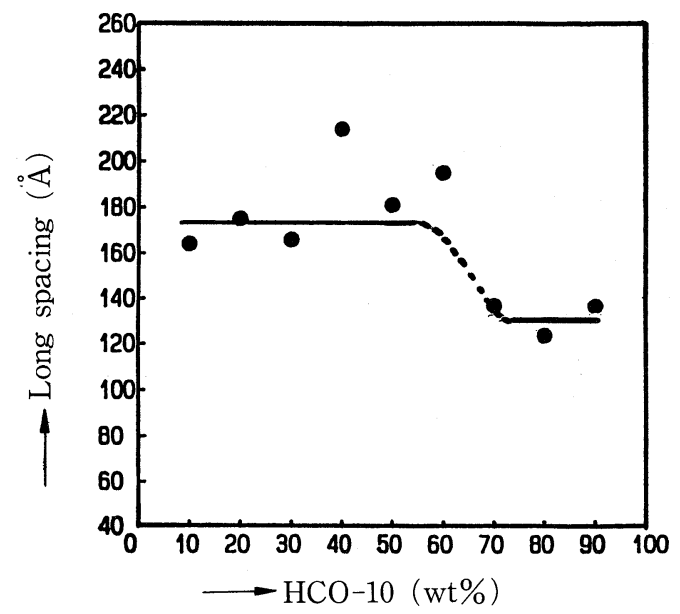

Fig.-6 Plots of long spacing as a function of $\mathrm{HCO}-10$ concentration at $25^{\circ} \mathrm{C}$.

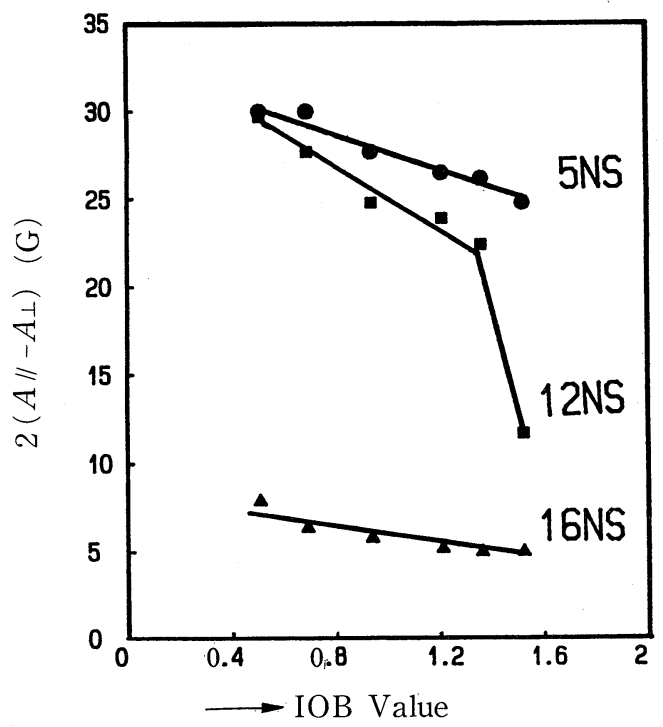

Concn. : 10 wt \% for each run

Fig. -7 Plots of $2\left(A_{/ /}-A_{\perp}\right)$ for various spin probes against IOB values of $\mathrm{HCO}$ at $25^{\circ} \mathrm{C}$.
Fig. -6 は $25^{\circ} \mathrm{C}$ における小角 $\mathrm{X}$ 線回折測定による $\mathrm{HCO}-10$ の濃度と長面間隔の関係を示す。長面間隔は HCO-10 の濃度が 10〜60 wt \% で, 170〜 180 ^ とほぼ 一定であった。しかし，70 wt\% 以上では $130 \AA$ に減少 した。水分含有量が $30 \mathrm{wt} \%$ 以下の等方性ゲル溶液で は自由水が存在せず，すべて HCO の結合水になってい るが, 水分含有量が $40 \mathrm{wt} \%$ 以上の液晶状態では一部 が自由水となり, 二分子層間に浸入したため長面間隔が 増加したものと思われる。

Fig. -5 及びFig. -6 に示すように, Fig. -3 に示した 二ート相液晶内でのベシクル形成領域と二分子膜（ラメ ラー液晶）形成領域における会合状態の差異は本研究で 行った ESRによる異方性の測定及び小角散乱X線回折 法では識別することができなかった。この理由は HCO-10 ベシクルが MLV 構造で, 平均粒子径約 430 $\mathrm{nm}$ と大きく, その曲率が小さくなるので, ベシクル状 態の HCO-10 分子の配向状態は二分子膜（ラメラー液 晶）状態の配向性とミクロな視野では变わらないためと 推定される。

一方, Table-1 に示したように, HCO のベシクル形 成性には, HCO 分子の IOB 值が重要な役割を果たして いると考えられる。

Fig.-7 は HCO 誘導体の IOB 值と各種スピンプロー ブの異方性パラメーターとの関係を示す。IOB 值が大 きくなると（すなわち, $\mathrm{HCO}$ 分子の親水性部位の割合 が増す）と, $\mathrm{HCO}$ 会合体の深さ方向に標識した各種ス ピンプローブの異方性パラメーターの值はいずれも連続 的に減少した。この異方性パラメーターは, IOB 值の増 加之共に HCO 会合体の表面近傍 (5 NS) と会合体の内 部 (16 NS) では単調に減少するのに対して, HCO 会合 体の中間部位 (12 NS) では著しく減少した。すなわち, $\mathrm{HCO}$ 会合体は均一な膜構造ではなく, $\mathrm{HCO}$ 分子の長 鎖中間部位すなわち長鎖に付加している $(\mathrm{EO})$ 基が分散 媒等の極性に対し, 極めて感応しやすい部位であること が明らかになった。

〔平成 4 年 (1992 年) 3 月 24 日受理〕

\section{文献}

1) A.D. Bangham, M.M. Standish, J.C. Watkins, J. Mol. Biol., 13, 238 (1965)

2) V. K. Miyamoto, T. E. Thompson, J. Colloid and Interfac. Sci., 25, 16 (1967)

3) Y. Toyoshima, K. Kurihara, Yukagaku, ., 26, 597 (1977)

4) S. Noro, F. Ishi, Yukagaku, 31, 146 (1982)

5) 国武豊喜, 岡畑恵雄, 化学の領域, 34, 480 (1980)

6) J. Sunamoto, H. Kondo, A. Yoshimatsu, Biochim. Biophys. Acta., 510, 52 (1978)

7) S. Mann, J.P. Hannington, R.J.P. Williams, Nature, 1324, 565 (1986) 
8) T. Kunitake, Y. Okahata, J. Am. Chem. Soc., 99, 3860 (1977)

9) T. Kunitake, Y. Okahata, M. Shimomura, S. Yasunami, K. Takarabe, J. Am. Chem. Soc., 103, 5401 (1981)

10) R.M. Handjiani-Vila, A. Ribier, B. Rondot, C. Vanlerberghie, I.J. Cosmet. Sci., 1, 303 (1979)

11) A.J. Baillie, A.T. Florence, L.R. Hume, G.T. Muirhead, A. Rogerson, J. Pharm. Pharmacol., 37, 863 (1985)

12) Y. Okahata, S. Tanamachi, M. Nagai, T. Kunitake, J. Colloid and Interfac. Sci., 82, 401
(1981)

13) K. Tajima, E. Takagi, T. Horiuchi, M. Tanaka, Proceedings of Section Lectures and Scientific Presentations on ISF-JOCS World Congress, Vol. II, 741 (1988)

14) M. Tanaka, H. Fukuda, T. Horiuchi, J. Am. Oil. Chem. Soc., 67, 55 (1990)

15）藤田 穆, 化学の領域, 11, 719 (1957)

16) J.W. Mcbain and W.W. Lee, Oil and Soap, 20, 17 (1943)

17）水沼仁宏, 粧技誌, 3,10 (1966)

18）山口潮三, 早川 勉, 油脂, 37 (12), 77 (1984) 